\title{
Investigation of the Prevalence of Anabolic Steroid Misuse, as Well as the Awareness Level and Attitude toward its Negative Effects among the Male Bodybuilder Athletes in Kermanshah, Iran, in 2019
}

\author{
Mehry Hoseini $^{1}$ (D), Bahram Yousefi ${ }^{*}$ (iD), Ali Ashraf Khazaei ${ }^{1}$ \\ ${ }^{1}$ Dept of Sport Management, Faculty of Sport Sciences, Razi University, Kermanshah, Iran
}

Article Info

Article type:

Research article

Article History:

Received: 01 February 2021

Revised: 22 February 2021

Accepted: 29 June 2021

\footnotetext{
* Correspondence to:

Yousefi Bahram

Dept of Sport Management, Faculty of Sport Sciences, Razi University, Kermanshah, Iran Email:

bahramyoosefy@yahoo.com
}

\author{
A B S T R A C T
}

Introduction: There have been several reports showing that the rate of anabolic-androgenic steroid abuse has increased in athlete and nonathlete adolescents. Therefore, this study aimed to assess the prevalence of anabolic steroid misuse, as well as the awareness level and attitude toward its negative effects on male bodybuilder athletes in Kermanshah, Iran.

Material \& Methods: This descriptive cross-sectional study was conducted in 2019. The statistical population included all male bodybuilder athletes in Kermanshah, Iran. The data were collected using a 25- item self-reported anabolic-androgenic steroids questionnaire (demographic characteristics: $n=7$, awareness level: $n=9$, attitudes: $n=5$, and the prevalence of abuse: $n=5$ ) which was distributed using the multistage clustering method among 250 male bodybuilder athletes in Kermanshah, Iran. The obtained data were analyzed in SPSS software (version 22) through descriptive statistics (frequency, percentage, mean \pm SD) and inferential statistics (Pearson correlation coefficient). A p-value less than 0.05 was considered statistically significant.

Findings: The results indicated that anabolic-androgenic steroid use was prevalent in $65.2 \%$ of the subjects. The most common cause was to increase muscle mass and strength. According to the results of this study, the prevalence of androgenic-androgenic steroid use showed a significant inverse relationship with attitude $(\mathrm{r}=-0.78 ; \mathrm{P}=0.021)$, awareness $(\mathrm{r}=-0.73$; $\mathrm{P}=0.032)$, an education level $(\mathrm{r}=-0.79 ; \mathrm{P}=0.022)$. Moreover, sports background correlated significantly with the prevalence of androgenicandrogenic steroid use $(\mathrm{r}=0.68 ; \mathrm{P}=0.035)$, attitude $(\mathrm{r}=0.84 ; \mathrm{P}=0.013)$, and awareness $(\mathrm{r}=0.85 ; \mathrm{P}=0.012)$.

Discussion \& Conclusion: The findings of this study indicated the high dose of anabolic-androgenic steroid use; moreover, the awareness level of the athletes was low in this regard. The low level of awareness, false attitude, and access to these steroids can lead to an increase in the use of them among athletes and different populations. Accordingly, health care professionals and sports specialists should consider these issues in the development of prevention plans and programs.

Keywords: Anabolic steroids, Athlete, Attitude, Awareness

$>$ How to cite this paper

Hoseini M, Yousefi B, Ashraf Khazaei A. Investigation of the Prevalence of Anabolic Steroid Misuse, as well as the Awareness Level and Attitude toward its Negative Effects among the Male Bodybuilder Athletes in Kermanshah, Iran, in 2019. Journal of Ilam University of Medical Sciences. 2021;29(5): 22-31. 


\section{بررسى شيوع سوءمصرف استروئيدهاى آنابوليك و ميزان آكاهى و نكرش از ييامدهاى

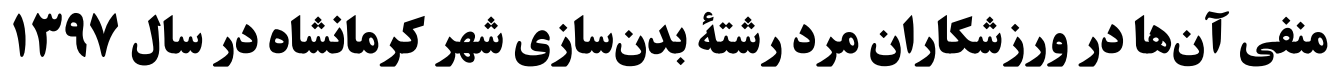

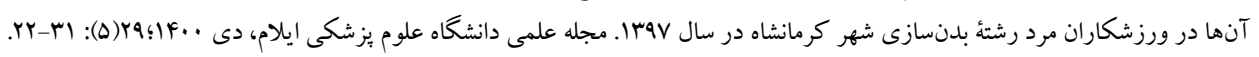


كليهها، دستخاه هورمونى، توليدمثل، تغيير فاكتورهاى خونى، اختلالات روانى اجتماعى، ريزش مو و رشد موهاى زائد آنابوليكك اثر منفى دارد (Y)، Y). سو كاس و همكاران

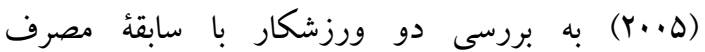
استروئيدهاى آنابوليك- آندروزنيكك به مدت ها لهال سال و ديخرى به مدت هشت هفته برداختند كه در اولى دو تومور

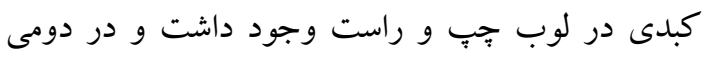

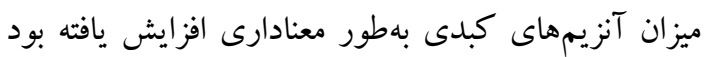

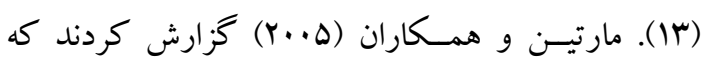

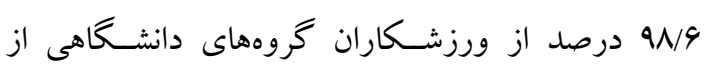
داورهاى نيروزا استفاده مى كند (If). نجومى و بهروان

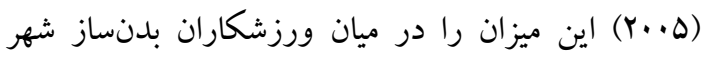
كرج rا درصد بيان كردهاند (ها). كاشى و همكاران

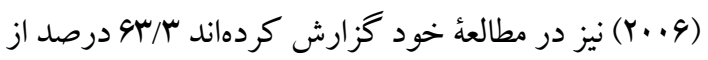

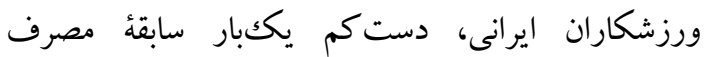
استروئيدهاى آنابوليك- آندروزنيكك را دارند (19). در

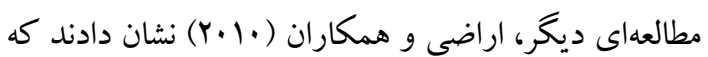
9V درصد از ورزشكاران رشتهُ هرورش اندام در شهر رشت استروئيدهاى آنابوليك- آندروزنيك مصرف نمودهاند

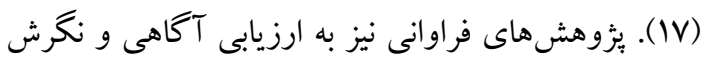

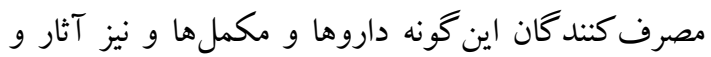
عوارض جانبى اين داروها يُرداختند و نشان دادند كه

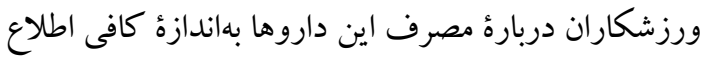
نداشتهاند و نخرش منفى نداشتن آنان باعث دقت كمتر در انتخاب اين داروها شده است (NIV)؛ مطالعاى به بررسى ميزان آكاهى ورزشكاران نوجوان آمريكايى دربارة استروئيدهاى آنابوليك- آندروزنيك

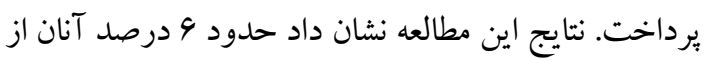

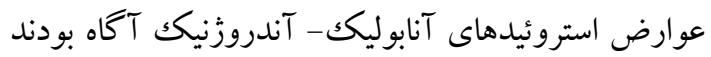
كه اين افراد هم اطلاعات را از والدين، مربى و معلم خود الديد دريافت كرده بودند (19). با توجه به نتايج مطالعاتى كه بخشى از آنها بيان شد،

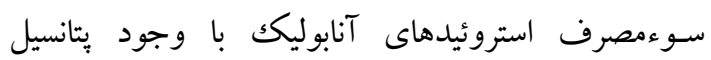

در سالهاى اخير، توجه به ويزگ گهاى جسمانى و ظاهر خود بهويزه افزايش حجم و تودهُ عضلانى، ازجمله مسائلى كه نظر جوانان و نوجوانان بسيارى را به خود جلب كرده و سبب افزايش اختلال تغذيهاى اين افراد شده است (1). از

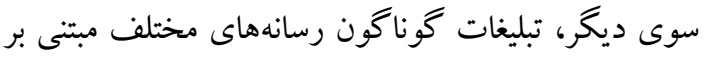

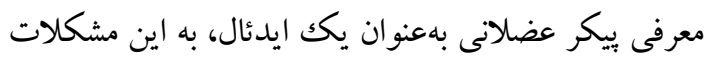

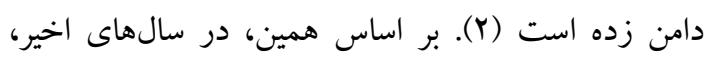
جو انان و نوجوانان بسيارى به ورزش بدنسازى رو آوردند؛

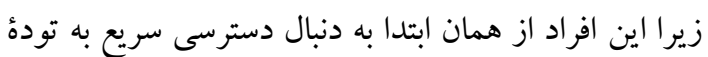

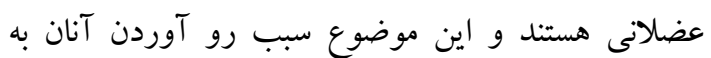

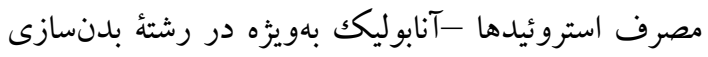

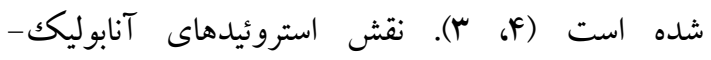
آندروزنيك در ورزش انكارنشدنى است. آنابوليك استيك وازهاى يونانى است و به رشد تدريجى و ساختهدن اشاره

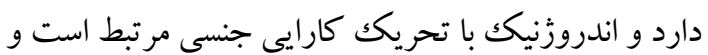
مسبب بروز صفات مردانه نيز است (ه). استروئيدهاى

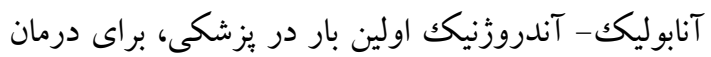

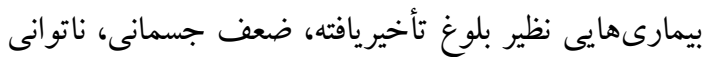
جنسى و ساير بيمارىها استفاده شدند (V)، 9)؛ محققان

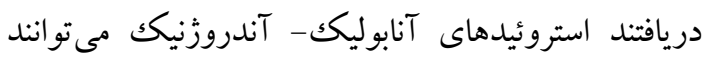
رشد عضلات اسكلتى رادر جانوران آزمايشكاهى تقويت كنند. پِ از اين اكتشاف، نخستين بار وزنهبرداران و بدنسازان و سبس ورزشكاران ساير رشتهاى ورزشى اين

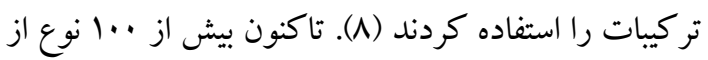
استروئيدهاى آنابوليك- آندروزنيك توليدشده است و بعضى به شكل خوراكى و بعضى به شكل تزريقى درونعضلانى و بعضى به شكل زل و كرم مصرف مى شوند

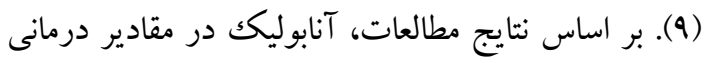
روى قدرت عضلانى و عملكرد فرد در مسابقات اثر ندارد؛ اما مقادير دارويى كه ورزشكاران رشتهٔ بدنسازى مصرف

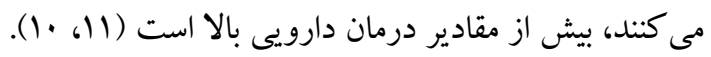

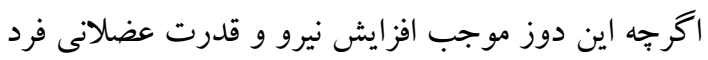
مىشود؛ اما سوءمصرف آن بر كبد، دستخاه قلب و عروق، 
يرسشنامهُ جند يُوهشخر بينالمللى متخصص در اين زمينه اقتباس شده بود ( آY، ·Y). براى اولين بار، اراضى و

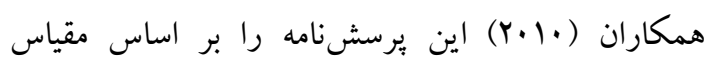
ليكرت استفاده كردند و روايى و يايايى آن را در سطح

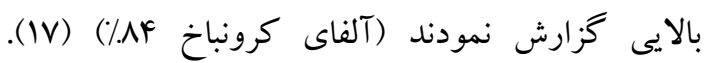
كفتنى است اين يرسشنامه سؤالات مختلفى براى اندازهگيرى ميزان آكاهى، نكرش و شيوع مصرف استروئيدهاى آنابوليك- آندروزنيك دارد و در دو بخش مئ تدوينشده است: بخش اول شامل اطلاعات جمعيتشناختى سن و ميزان تحصيلات و بخش دوم شامل V مورد براى اطلاعات زمينهاى، 9 مورد مربوط به آكاهى (دامنهُ امتياز ا با كمترين آكاهى و هو ه امتياز بيشترين آكاهى)، أ مورد مربوط به نخرش (دامنه امتياز 1 با كمترين نكرش و \& امتياز بيشترين نكرش) و ه مورد مربوط به شيوع سوءمصرف است. يس از رجوع به باشگاههاى منتخب و جلب رضايت مسئول باشگاه و ورزشكاران مبنى بر همكارى صادقانه آنان، يرسشنامهها ميان ورزشكاران توزيع گرديد و از آنان خواسته شد تا با دقت به سؤالات مدنظر جواب دهند. درنهايت، يرسشنامههاى تكميلشده از سوى محقق جمع آورى كرديد. ابتدا اطلاعات موجود در همهُ برسشنامهها كد گذارى شد و توسط نرمافزار SPSS vol.22 در سطح معنادارىه •. P شامل فراوانى، درصد، ميانگين و انحراف استاندارد شاخصها استفاده شد؛ همجنين ارتباط ميان متغيرهاى كمى با استفاده از آزمون ضريب همبستكى بيرسون سنجيده گرديد.

\section{يافته ها}

اطلاعات مربوط به ميانگين و انحراف استاندارد سن، وزن و قد آزمودنىها در جدول شمارهُ ا ارائهده است.

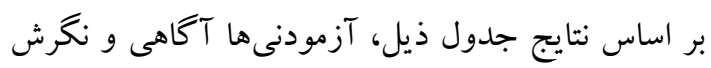
ضعيفى از ييامدهاى منفى استروئيدهاى آنابوليكآندروزنيكك داشتند.
خطرزايى كـه دارد، شيوع فراوانى در سراسر جهان داشته است و كشـور مـا نيـز از اين قاعده مستثنا نيست، به گونهاى كه بر اساس گَزارشهـاى حدود، در برخى از استانها و

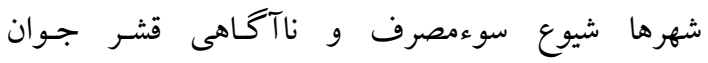
ورزشـكار و استفاده از روش كاذب توسعهدهندهُ عملكرد جسمانى بدنى كه مسلماً بيامدهاى بهداشـتى ســـين بـراى جامعه به همـراه دارد، دغدغـهـاى بسـيارى را در بعـد يزشـى و ورزشى ايجاد كرده است، حال آنكه اين نكرانى در كلانشهرها، بهواسطة جمعيت انسانى فراوان، نبود نظارت كافى نهادها و دستخاههاى مسئول، دسترسى آسان و نبود اطلاعرسانى بهنگام و درست، بيشتر است و جذبههاى ظاهرى و مقطعى اين مواد مىتواند سائُ سـنَين خود را بر

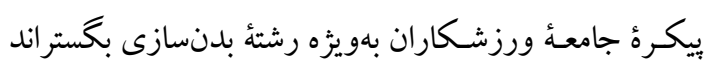
و آنان رادر معرض تهديد جدى قرار دهد. بر اساس همين، اين مطالعه با هدف بررسى سوءمصرف استروئيدهاى آنابوليكك در ميان ورزشكاران مرد بدنساز شهرستان كرمانشاه و آكاهى و نخرش آنان نسبت به عوارض جانبى صورت كرفت تـا بـر اسـاس نتايج ايـن مطالعه، نخرش عميق تر و اطلاعات بيشترى بهدست آيد.

\section{مواد و روش ها}

اين مطالعه از نوع توصيفى است كه بهصورت مقطعى انجام شد. جامعهُ آمارى مطالعهُ حاضر، همهُ مردان مراجعه كننده به باشگاههاى بدنسازى سطح كرمانشاه (افرادى كه بيش از شش ماه و سه روز در هفته تمرين منظم داشتند) تشكيل دادند. از ميان آنان بر اساس جدول

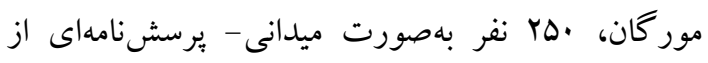
باشگاههاى مختلف، در بازهُ زمانى شهريور تا آبان ماه سال IMqV انتخاب گرديدند. بر اساس همين، شهر كرمانشاه از نظر موقعيت جغرافيايى به ينج منطقه شمال، جنوب، شرق، غرب و مركز تقسيم و از هر منطقه به نسبت

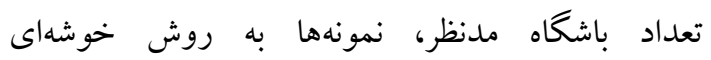
جندمر حلهاى بهطور كاملاً تصادفى انتخاب شدند. در اين تحقيق، از يرسشنامئ ها سؤالى استفاده كرديد كه از 
جدول شماره ا. ميانخين و انحراف استاندارد ويز گیىهاى توصيفى آزمودنىها

\begin{tabular}{|c|c|c|c|c|}
\hline ميزان نكرش & ميزان آكاهى & قد (سانتىمتر) & وزن (كيلوكرم) & سن (سال) \\
\hline $1 / \% \pm \cdot / \cdot 9$ & $4 / 9 \pm \cdot / 91$ & $|V G / 9 \pm| Y / F \wedge$ & $V r / V 9 \pm 9 / V r$ & $r F / 19 \pm \cdot / r$ \\
\hline
\end{tabular}

درصد، بلدون سابقه قهرمانى بودند. علاوه بر اين، هيج كدام از ورزشكاران تجربهُ قهرمانى در سطح آسيا (قارهاى) و

قهرمانى در سطح جهان در ميان ورزشكاران رانداشتند. يافتهاى جدول شمارهُ ب نشان داد همئ آزمودنىها باسواد بودند و بيشترين درصد آزمودنىها مدرك
يافتهاى جدول شماره ب نشان مىدهد كه هيج كدام از ورزشكاران كمتر از 9 ماه سابقه ورزشى نداشتند و بيشترين آزمودنىها 4 الى بالى ماه سابقه ورزشى داشتند كه معادل r/ץ دورصد هستند؛ همجنين بر اساس نتايج جدول شماره rا، از مجموع ورزشكاران تعداد 191 نفر معادل نو

جدول شمارة r. سابقهُ ورزشى و سابقهُ قهرمانى افر اد شر كت كننده در مطالعه

\begin{tabular}{|c|c|c|c|c|c|}
\hline درصد & تعداد & سابقهُ قهر مانى & درصد & تعداد & سابقهُ ورزشى \\
\hline$V Q / r$ & 191 & بدون سابقهُ قهرمانى & · & · & كمتر از 9 ماه \\
\hline $1 N / \Lambda$ & FV & قهرمانى در سطح منطقه (استانى) & $\Delta q / r$ & $\mid F \lambda$ & و الى rا ماه \\
\hline r & $\Delta$ & قهرمانى در سطح ملى (كشورى) & $r \cdot / \Lambda$ & $\Delta r$ & الى ب الى سال \\
\hline . & · & قهرمانى در سطح آسيا (قارهاى) & 19 & f. & ب الى F سال \\
\hline · & · & قهرمانى در سطح جهان & f & 1. & بيش از F سال \\
\hline
\end{tabular}

جدول شماره r. سابقهُ تحصيلى، ميزان سوءمصرف، روش مصرف و دلايل مصرف اصلى استروئيدهاى آنابوليك - آندروزنى

\begin{tabular}{|c|c|c|}
\hline درصد & تعداد & سابقهُ تحصيلى \\
\hline 1. & ro & كمتر از دييلم \\
\hline 19 & f. & دييلم \\
\hline r. & $\Delta$. & كاردانى \\
\hline$M r / Y$. & $\Delta r$ & كارشناسى \\
\hline 11 & ra & 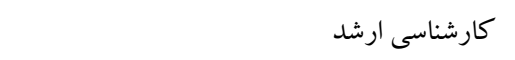 \\
\hline$r / \Lambda$ & $\checkmark$ & 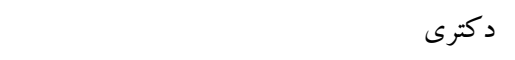 \\
\hline مرصد & 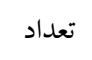 & سابقهُ مصرف استروئيدهاى آنابوليك - آندروزنى \\
\hline $90 / r$ & 194 & بلى (كذشته و حال) \\
\hline$\mu F / \Lambda$ & $\Lambda V$ & خير \\
\hline د درصد & 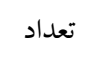 & روش مصرف استروئيدهاى آنابوليك - آندروزنى \\
\hline Fq & 11. & 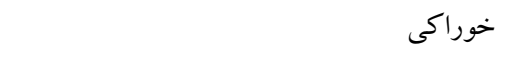 \\
\hline ra & 9. & ت تزريقى \\
\hline r. & $\Delta \cdot$ & 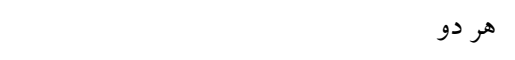 \\
\hline مرصد & 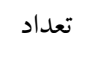 & دلايل اصلى مصرف داروها \\
\hline rN/1 & १V & افزايش تودهُ عضلانى \\
\hline$r Y / r$ & $\Delta r$ & 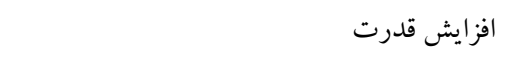 \\
\hline $9 / 9$ & rF & افزايش سرعت \\
\hline $\mid r / r$ & r & 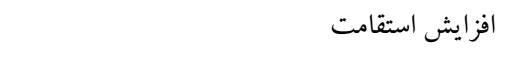 \\
\hline$I V / r$ & kr & 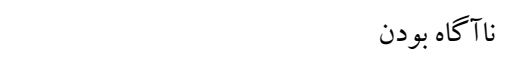 \\
\hline $1 \cdots$ & ro. & جمع كل \\
\hline
\end{tabular}




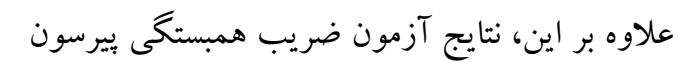

در جدول شماره F نشان داد كه ميان سابقه ورزشى با شيوع مصرف استروئيدهاى آنابوليك-آندروزنى، آكاهى و نخرش دربارهء مصرف آن در ميان آزمودنىها، رابطة مثبت و معنادارى مشاهده شد؛ بهعبارتديخر، با افزايش سابقه ورزشى و ميزان شيوع مصرف استروئيدهاى آنابوليك-آندروزنى، نخرش و آكاهى درست نسبت به آنها افزايش مى يابد؛ همجينين يافتهها نشان داد كه ميان سطح تحصيلات و شيوع مصرف استروئيدهاى آنابوليك-آندروزنى، رابطةٌ منفى و معنادار مشاهده شد و ميان سطح تحصيلات با آكاهى و نخرش دربارهٔ مصرف استروئيدهاى آنابوليك-آندروزنى در بين آزمودنىها،

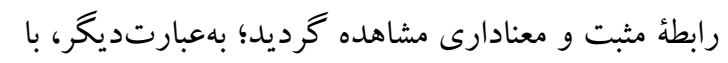

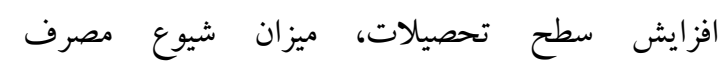

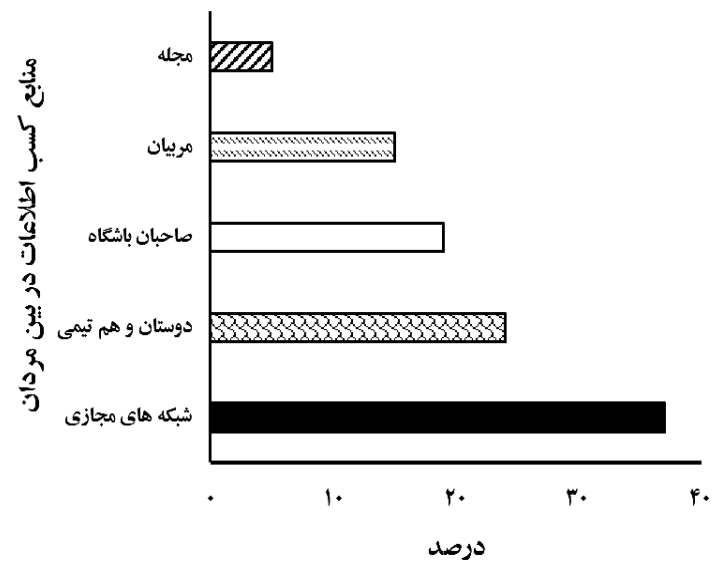

شكل شماره أ. منابع كسب اطلاعات دربارهٔ مصرف استروئيدهاى درد آنابوليك- آندروزنى

كارشناسى داشتند. علاوه بر اين، نتايج جدول شمارهء نشان داد كه مصرف استروئيدهاى آنابوليك در ميان بدنسازان شركت كننده در اين مطالعه بسيار بالا است، به گونهاى كه سوا نفر معادل 40/Y درصد، اين داروها را مصرف مى كردند كه از ميان، FF درصد بهصورت خوراكى، צr درصد بهصورت تزريقى و ·r درصد از هر دو روش (خوراكى، تزريقى) بهطور همزمان استفاده

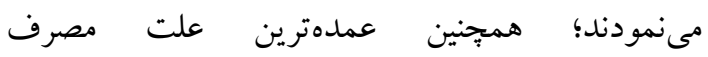
استروئيدهاى آنابوليك- آندروزنى افزايش تودهُ عضلانى و قدرت بود و در اين ميان نكته جالب اين است كه سم نفر معادل IV/Y دليلى براى مصرف داروها نداشتند. نتايج شكل شمارة ا نشان مىدهد كه مهمترين منابع كسب اطلاعات دربارهُ مصرف استروئيدهاى آنابوليكآندروزنى در ميان آزمودنىها به ترتيب شبكههاى مجازى جدول شمارهُ ع. رابطة ميان متغيرهاى مرتبط با استروئيدهاى آنابوليك-آندرورنى

\begin{tabular}{|c|c|c|c|c|}
\hline ن & آكاهى & شيوع & آزمون & متغير ها \\
\hline$r=-0.73$ & $r=-0.78$ & - & ضر يب همبستكى & شيوع مصرف استروئيدهاى \\
\hline $\mathrm{P}=0.32^{*}$ & $\mathrm{P}=0.021^{*}$ & - & سطح معنادارى & آنابوليك-آندروزنى \\
\hline $\mathrm{r}=0.85$ & $\mathrm{r}=0.84$ & $r=0.68$ & ضر يب همبستكى & \multirow{2}{*}{ سابقهُ ورزشى } \\
\hline $\mathrm{P}=0.012^{*}$ & $\mathrm{P}=0.013^{*}$ & $\mathrm{P}=0.035^{*}$ & سطح معنادارى & \\
\hline $\mathrm{r}=0.75$ & $r=0.64$ & $r=-0.79$ & ضر يب همبستگى & \multirow{2}{*}{ سطح تحصيلات } \\
\hline $\mathrm{P}=0.030 *$ & $\mathrm{P}=0.042 *$ & $\mathrm{P}=0.022 *$ & سطح معنادارى & \\
\hline
\end{tabular}


درحالى كه در مطالعات ديخر، ميانخين سنى مصرف اين

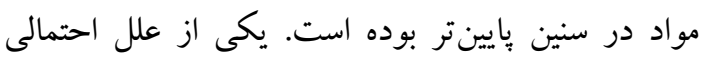
بالاتر بودن ميانخين سن شروع سوءمصرف استروئيدهاى آنابوليك اين بود كه در آزمودنىهاى شر كت كننده در اين مطالعه، تعداد 194 معادل VQ/Y درصد آزمودنىها سابقه

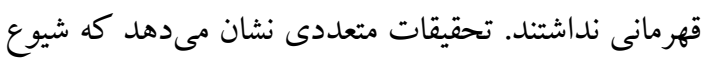
اين داروها در ميان ورزشكاران نسبت به غيروزشكاران

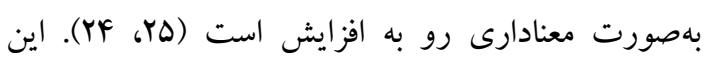

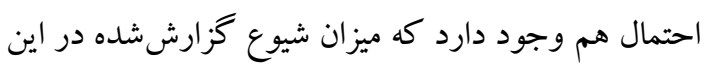
مطالعه بالاتر از اين هم باشد؛ زيرا به علل محافظه كارانه ممكن است همهٔ مصرف كنند كان اين داروها به مصرف آن آن اعتراف نكرده باشند. به نظر مىرسد با توجه به به ورود و و

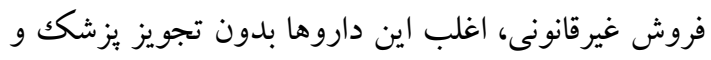
با توصئ برخى دوستان، مربيان و دلالها مصرف مىشود

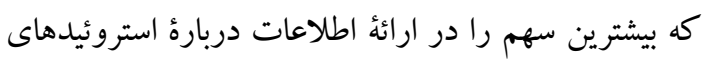

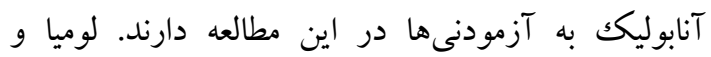

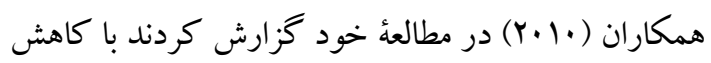
در دسترس بودن استروئيدهاى آنابوليك-آندروزنى، قرار دادن قوانين سرسخت براى خريدوفروش آن، آموزش نوجوانان دربارة آثار كو تاهمدت و بلندمدت استروئيدهاى آنابوليك-آندروزنى و آكاهى از عواقب احتمالى استفاده از استروئيدهاى آنابوليك-آندروزنى مىتوان مصرف آن

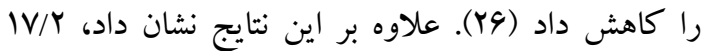
درصد از آزمودنىهاى شر كت كننده در اين مطالعه مدعى دائ بودند اطلاعات كافى دربارة استروئيدهاى آنابوليكآندروزنيك دارند. اين كفتئ آزمودنىها با ميزان

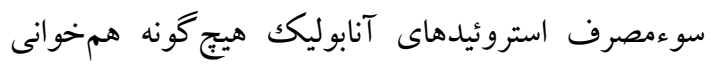
ندارد و تنها باورهاى اشتباه و نادرست افراد شر كت كننده

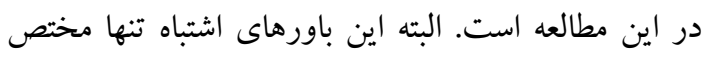

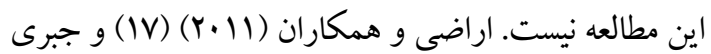

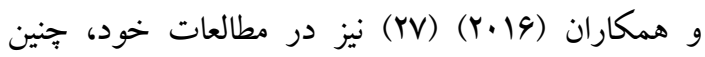
باورهاى اشتباه و نادرستى را كزارش كردند؛ همجِينين نتايج اين مطالعه نشان داد افراد شر كت كننده در اين مطالعه معتقد بودند كه متخصصان اصلى درباره استروئيدهاى آنابوليك
استروئيدهاى آنابوليك-آندروزنى كاهش و آكاهى و نخرش دربارة عوارض مصرف آنان افزايش مىيابد.

بحث و نتيجه كيرى

استعمال استروئيدها يكى از جالشهاى

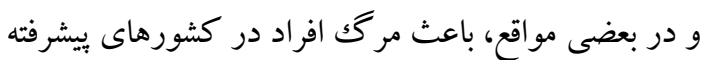
و درحالتوسعه بهشمار مىرود (IN IV). هدف از اين مطالعه، بررسى شيوع سوءمصرف و آكاهى از عوارض جانبى و نخرش نسبت به استروئيدهاى آنابوليك در ميان مردان بدنساز شهرستان كرمانشاه بود. استفاده نادرست از

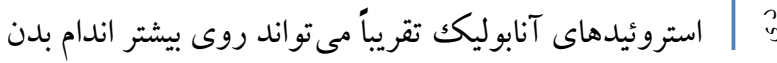
تأثير مخرب بكذارد و ارتباط آن با سرطان كبد، حملئ قلبى، عوارض جانبى متعدد آكنه، كيستهاى خربى، يوست و مو شناختهشده است (א)، ץ). با توجه به توليد انبوه استروئيدها و تبليغات گسترده و ورود و فروش غيرقانونى و بدون تجويز يزشك و كسب اطلاعات از شبكهاى مجازى، دوستان و همتيمىها، صاحبان باشگاه، مربيان و مجلهها بيشترين سهم را در اين مطالعه دارند. يافتههاى مطالعة حاضر نشان مىدهد 90/r درصد از آزمودنىهاى شركت كننده در اين مطالعه از اين داروها استفاده مى كنند

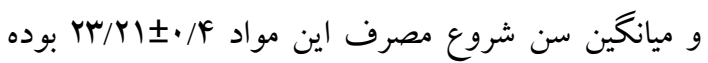

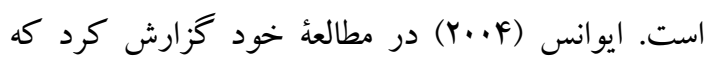
حدود ب ميليون مورد سوءمصرف استروئيدهاى آنابوليك-

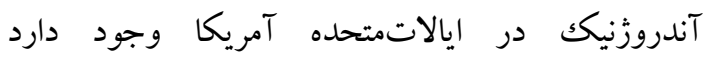
كه دوسوم آنان بدنسازان تفريحى غيررقابتى يالياه

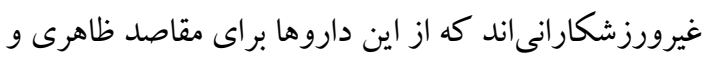

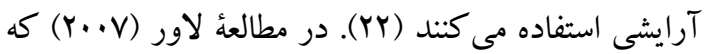

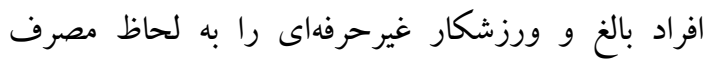

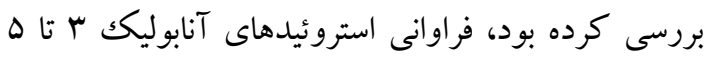

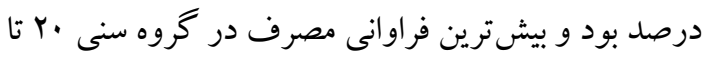

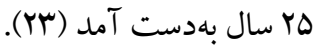
همانطور كه در بالا بيان شد، نتايج مطالعه حاضر نشان

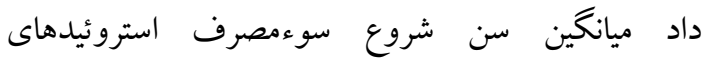
آنابوليك-آندروزنى در آزمودنىها 
نتايج مطالعه حاضر نشان داد ميان سابقه ورزشى با

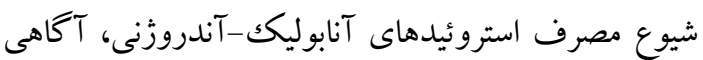

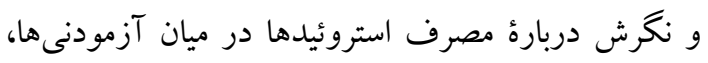

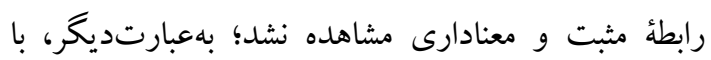

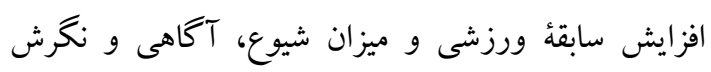

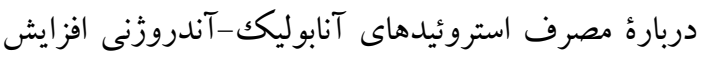

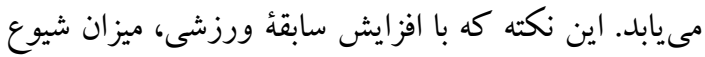

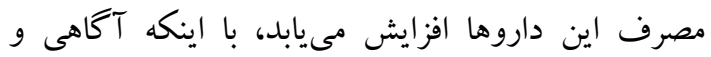

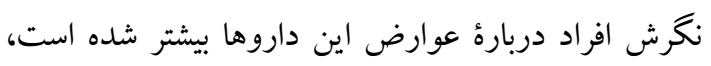

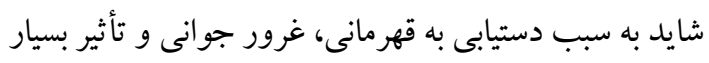

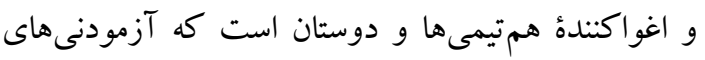

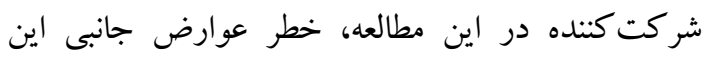
داروها را به جان مىخرند و از اين داروها استفاده مى كنند. يافته مطالعة حاضر با نتايج مطالعات صالح و همكاران

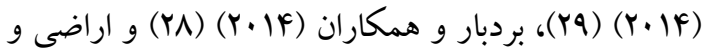

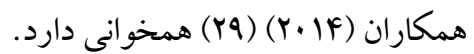
نتايج نشان داد كه ميان سطح تحصيلات و شيوع مصرف استروئيدهاى آنابوليكك-آندروزنى رابطة منفى و معنادار و بين سطح تحصيلات با آكاهى و نكرش دربارهٔ مصرف استروئيدها در ميان آزمودنىها، رابطة مثبت و

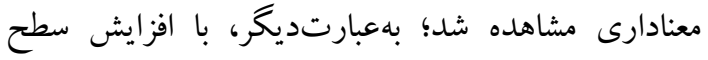

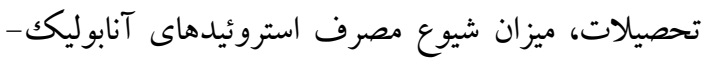

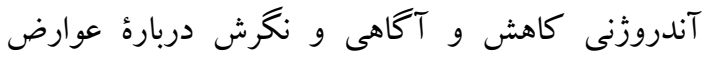
مصرف استروئيدهاى آنابوليك-آندروزنى افزايش مهى يابد.

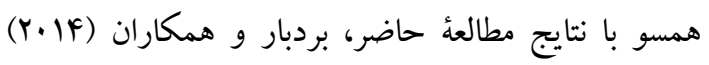

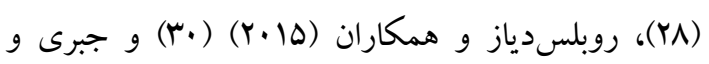

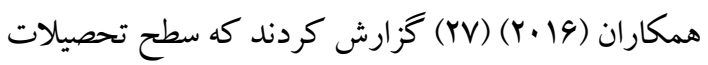

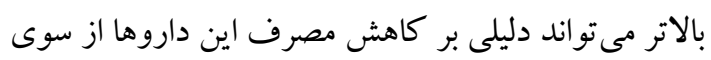

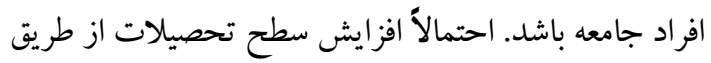

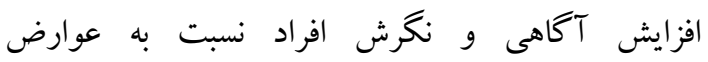
سوءمصرف استروئيدهاى آنابوليك - آندروزنى سبت اهري كاهش مصرف اين مواد كردد.

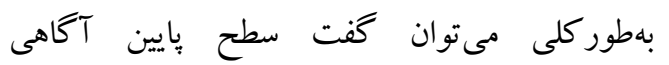

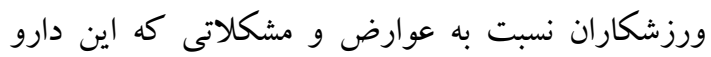

افرادى هستند كه سابقهُ ورزشى بيشتر و همجنين سابقة مصرف دارويى بيشترى داشته باشند. علاوه بر اين نتايج

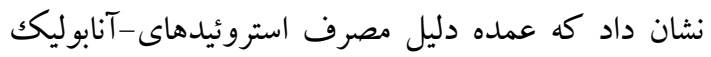
در ميان آزمودنىها به ترتيب افزايش تودة عضلانى (تعداد

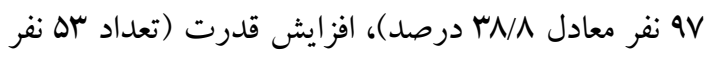

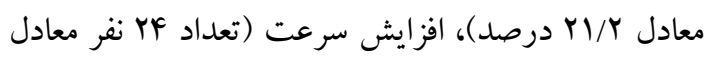

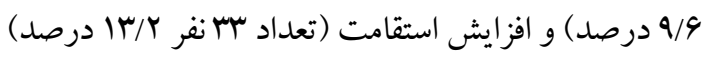

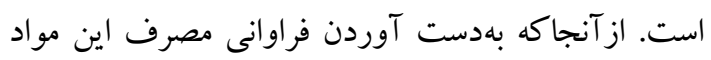
مشكل است و اغلب از سوى افراد مصرف كننده انكار

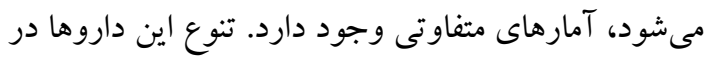

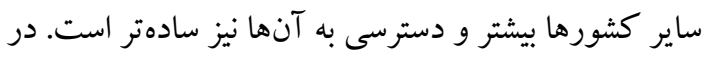

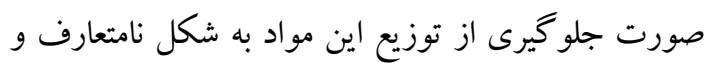

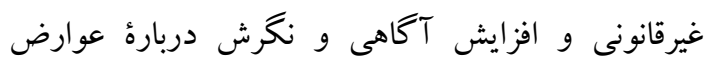
سوءمصرف استروئيدهاى آنابوليك-آندروزنى، احتماني أنمالاً شاهد كاهش مصرف اين مواد خو اهيم بود.

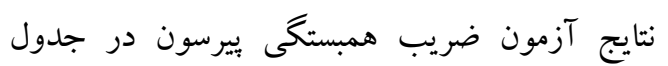

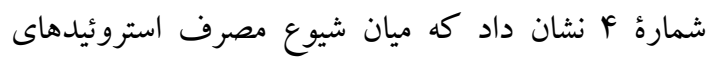
آنابوليك- آندروزنى با آكاهى و نخحرش آزمودنى ها دربارة مصرف استروئيدها، رابطة منفى و معنادارى مشاهده شد؛

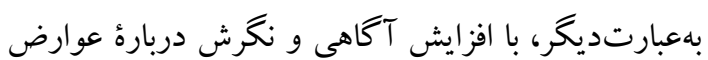
مصرف استروئيدهاى آنابوليك-آندروزنى، ميزان

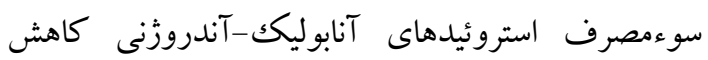
مىيابد. همسو با نتايج مطالعة حاضر، بردبار و همكاران

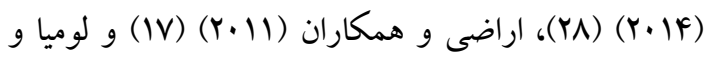

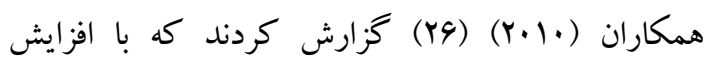

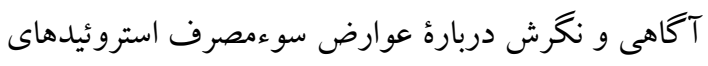

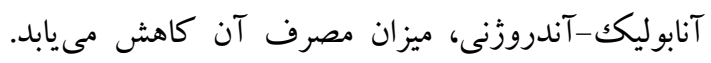
بهنظر مىرسد با توجه به نمايشى بودن و اهميت حجم و

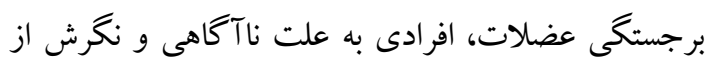
سوءمصرف داروهاى آنابوليك به بهاى كسب عضب حجم عضلانى بالاتر و ظاهرى بهتر در كوتاه زمان و وسوسههاى بهو بهاى

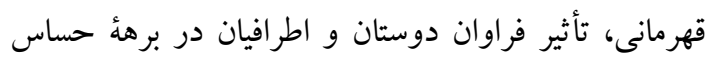

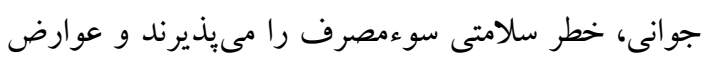

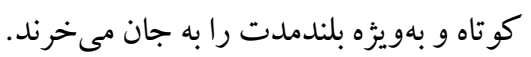


همكـارى نكردن مسئولان، مربيان و ورزشـكاران بـراى شـركت در ايسن گونـه يزوهشها اشاره كرد؛ بنابراين، ارائه نكردن اطلاعات صحيح مىتوانــ نقش اساسى در برآورد نادرست نتايج تحقيق درباره استروئيدهاى آنابوليك داشته باشد.

\section{تشكر و قدردانى \\ اين مقاله مستخرج از ياياننامهُ كارشناسى ارشد است \\ كه با كد . IFFqVG به تصويب دانشكدة تربيتبدنى و علوم ورزشى دانشخاه رازى رسيده و هيج گونه حامى

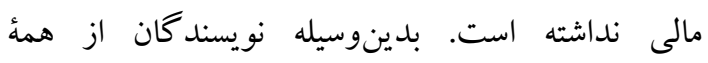 آزمودنى هايى كه ما رادر انجام اين مطالعه يارى نمودند، كمال تشكر و قدردانى را به عمل مى آورند. نويسند كان اين مطالعه هيج گونه تعارض منافعى ندارند.}

كد اخلاق: . IfFqve
براى سلامتى آنان دارد، زنگك خطرى براى آينده است و مىطلبد كه اقدامات جّندجانبه براى ارتقاى آكاهى ورزشكاران و مربيان باشخاههاى بدنسازى از سوى

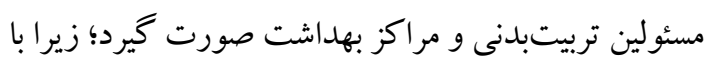
ورود ورزشكاران به مجامع قهرمانى، ميزان شيوع و مصرف استروئيدها در ميان آنان افزايش مىيابد؛ بنابر اين، كمكك به بهبود و سطح دانش ورزشكاران گام بلندى در بيشخيرى از سوءمصرف مواد استروئيد خواهد بود و آسيب كمتر جوانان و نوجوانان ورزشكار كشور را در بيى خواهد داشت؛ زيرا فرصت ورزش و فعاليت بدنى در مسير ارتقاى سطح آمادكى، بهبود عملكرد و تندرستى نبايد به تهديدات

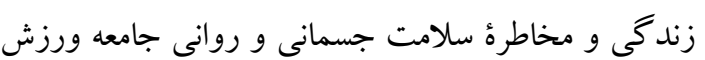
مبدل شود و اين زمانى اجرايى مى گردد كه مسئولان ورزشى، رسانهها و صاحبان باشگاهها و مربيان باشگاهها با همديخر هماهنكى لازم را براى اطلاعرسانى قوى به افراد داشته باشند. درنهايت، از محدوديتهاى اين مطالعه مىتـوان بـه

A. Assumption of anabolic-androgenic steroids among Isfahan University students: prevalence, and awareness about their side effects. 2006; 12(2):12-20. doi 10.22038/JFMH.2006.1805

9. Katzung BG. Basic and clinical pharmacology: McGraw-Hill Education; 2017; 3(2):33-40. doi.org/10.2344/0003-3006-60.1.25

10. Jean D. Androgens in, Goodman Gilman A; Rall TW, Nies AS. Goodman and Gilman's the pharmacological basis of Therapeutics. pergamon press, USA; 1991; 14(3):24-29. doi.org/10.1001/ jama.1997.03550060100050

11. Perry PJ, Andersen KH, Yates WRJTAjosm. Illicit anabolic steroid use in athletes: a case series analysis. 1990;18(4):422-8.doi.org/10.1177\%2F03 6354659001800416

12. Naghdi H, Mohammadi SJJoKUoMS. Prevalence and awareness of the side effects of anabolic steroid use among school students in Kurdistan, 2012. 2013;17(3):206-9. (Persian)

13. Socas L, Zumbado M, Perez-Luzardo O, Ramos A, Perez C, Hernandez J, et al. Hepatocellular adenomas associated with anabolic androgenic steroid abuse in bodybuilders: a report of two cases and a review of the literature. 2005;39(5): 27 33.doi.org/10.1136/bjsm.2004.013599

14. Kristiansen M, Levy-Milne R, Barr S, Flint AJIJoSN, Metabolism E. Dietary supplement use by varsity athletes at a Canadian university. 2005;15(2):195210. doi.org/10.1123/ijsnem.15.2.195

15. Nojoomi M, Behravan V. Study of anabolic

6. Achar S, Rostamian A, Narayan SMJTAjoc. Cardiac and metabolic effects of anabolic-androgenic steroid abuse on lipids, blood pressure, left ventricular dimensions, and rhythm. 2010; 15;106(6):893-901. doi: 10.1016/j.amjcard.2010.05.013

7. Street C, Antonio J, Cudlipp DJCJoAP. Androgen use by athletes: a reevaluation of the health risks. 1996;21(6):421-40. doi.org/10.1139/h96-038

8. Kargarfard M, GHIAS M, KarimZadegan A, Kashi 
steroids and the awareness of their complications in bodybuilding athletes in Karaj (2003). Razi Journal of Medical Sciences. 2005;11(44):1057-63. (Persian)

16. Kashi A, Kargarfard M, Moulavi H. Ergogenic substance in body building athletes: prevalence, cognitive and awareness of about their side effects. 2006;2(1):13-20. (Persian)

17. Arazi H, Hosseini R. The prevalence of anabolicandrogenic steroids abuse, knowledge and attitue of their side effects, and attitude toward them among the bodybuilding athletes in Rasht. Journal of Guilan University of Medical Sciences. 2011;20(80):34-41. (Persian)

18. Eskandarion M, Kheirvari Khezerloo J, Hemmatian S, Tabasi M, Ghorbani R. Prevalence of Anabolic Steroids among the Male Bodybuilding Athletes and Rate of Awareness to Side Effects in Shahrud. Iranian Journal of Forensic Medicine. 2019;25(1):1-7. (Persian)

19. Naqvi SY, Flaherty G. Knowledge, and Attitudes of Amateur Sports Participants Regarding the Cardiac Risks Associated with the Use of Anabolic-Androgenic Steroids. IOSR Journal of Sports and Physical Education. 2016:36-44. doi.org/10.9790/6737-03033644

20. Laure P, Lecerf T, Friser A, Binsinger CJIjosm. Drugs, recreational drug use and attitudes towards doping of high school athletes. 2004;25(02):133-8. doi.org/10.1055/s-2004-819946

21. Green GA, Uryasz FD, Petr TA, Bray CDJCjosm. NCAA study of substance use and abuse habits of college student-athletes. 2001;11(1):51-6. doi.org/10.1097/00042752-200101000-00009

22. Evans NA. Current concepts in anabolicandrogenic steroids. The American Journal of Sports Medicine. 2004;32(2):534-42. doi.org/ $10.1177 / 0363546503262202$

23. Laure $P$, Binsinger C. Doping prevalence among preadolescent athletes: a 4-year follow-up. British journal of sports medicine. 2007;41(10):660-3. doi.org/10.1136/bjsm.2007.035733

24. Mobasheri A, Proudman CJ. Cobalt chloride doping in racehorses: Concerns over a potentially lethal practice. The Veterinary Journal. 2015; 205(3):335-8. doi.org/10.1016/j.tvj1.2015.04.005

25. McNamee MJ. The spirit of sport and the medicalisation of anti-doping: empirical and normative ethics. Asian bioethics review. 2012; 4(4):374-92. doi.org/10.4324/9781003075004-22

26. Node K, Michishita R, Tsuruta T, Shono N, Inoue $T$. Effect of exercise therapy on monocyte and neutrophil counts in overweight women. The American journal of the medical sciences. 2010;339(2):152-6. doi.org/10.1097/maj.0b013e3181c6a980

27. Jabari M, Al-shehri H, Al-faris A, Al-sayed M, Algaeed F, Al-sobaie N, et al. The prevalence of anabolic androgenic steroid use amongst athletes in Riyadh (Saudi Arabia). Electronic physician. 2016;8(12):3343. doi.org/10.19082/3343

28. Fayyazi Bordbar MR, Abdollahian E, Samadi R, Dolatabadi H. Frequency of use, awareness, and attitudes toward side effects of anabolicandrogenic steroids consumption among male medical students in Iran. Substance use \& misuse. 2014;49(13):1751-8. doi.org/10.3109/10826084.2014.880175

29. Arazi H, Salehi A. Attitude and Awareness of Male Bodybuilders Toward Adverse Effects of Anabolic-androgenic Steroids in Qazvin, Iran. Iranian Journal of Epidemiology. 2014;9(3):45-53. (Persian)

30. Robles-Diaz M, Gonzalez-Jimenez A, Medina-Caliz I, Stephens C, García-Cortes M, García-Muñoz B, et al. Distinct phenotype of hepatotoxicity associated with illicit use of anabolic androgenic steroids. Alimentary pharmacology \& therapeutics. 2015;41(1):116-25. doi.org/10.1111/apt.13023 